\title{
Comparison between JCR and Qualis methods of classification of Brazilian journals on plant sciences
}

\author{
Leonardo Bianco de Carvalho
}

Professor at Centre of AgriVeterinarian Sciences of the Santa Catarina State University, Lages, Brazil, Ibcarvalho@cav.udesc.br.

JCR system is adopted as the method to evaluate the quality of scientific journals worldwide. However, in Brazil, scientific journals are classified with basis on the Qualis system. The system is also used to evaluate indirectly the Brazilian Post-Graduate Programs. The Qualis system is defined by the Coordination for the Improvement of Higher Level -or Education- Personel (CAPES) as a list of vehicles for dissemination of intellectual output of Post-Graduate Programs (Master and Doctorate). Post-Graduate Programs can be ranked by concepts 1 to 7 , so that the higher CAPES concept, the "higher quality" of Post-Graduate Program. Among other issues, this ranking is based on the average number of scientific papers published by the group of professors of a Post-Graduate Program and on the quality of the journals (Qualis system) in that papers are published, so that, in general, CAPES defines the amount of financial support available for some Post-Graduate Program in function of this ranking. Thus, the Qualis system is the most important method used for journal classification in Brazil.
The Qualis system of CAPES from Brazil evaluates the scientific journals according to the search platform in that journal is indexed and the Impact Factor (ISI JCR) of the journal. However, being not indexed in the Information Sciences Institute (ISI) does not decline the possibility of a journal having a Qualis concept. Many scientific journals are not indexed in ISI but have a Qualis concept. According to the Qualis system, journals can be classified as levels $A 1, A 2, B 1$, $B 2, B 3, B 4, B 5$ and $C$, so that $A 1$ is the best classification and $C$ is the worst one. In addition, the Qualis system arranges the journals by different areas of knownledge (eg. Agrarian Sciences I, Biological Sciences I, II or III, Geography, Biodiversity, Multidisciplinary, and so on). Thus, a unique journal can have different Qualis classification according to the area of knowledge of the papers published in the journal (eg. all journals pointed out in the Table 1 have a Qualis concept in at least three areas of knowledge, Agrarian Sciences I, Biological Sciences I and Biodiversity.

Table 1. Brazilian journals with both recent JCR 2010 and Qualis 2012, publishing papers on plant sciences with potential to be published by the journal Communications in Plant Sciences.

\begin{tabular}{|c|c|c|c|c|c|c|c|}
\hline \multirow{2}{*}{ Ranking } & \multirow{2}{*}{ Journal Title } & \multirow{2}{*}{ ISSN } & \multirow{2}{*}{$\begin{array}{c}\text { JCR } \\
\text { IF }\end{array}$} & \multicolumn{4}{|c|}{ Qualis } \\
\hline & & & & AS & BS & $\mathrm{BD}$ & Average \\
\hline 1 & Anais da Academia Brasileira de Ciências & 0001-3765 & 0.925 & A2 & B4 & B1 & 5.3 \\
\hline 2 & Scientia Agricola & 0103-9016 & 0.816 & $\mathrm{~A} 2$ & B4 & B1 & 5.3 \\
\hline 3 & Acta Scientiarum. Agronomy & $1679-9275$ & 0.805 & $\mathrm{~A} 2$ & B4 & B1 & 5.3 \\
\hline 4 & Neotropical Ichthyology & $1679-6225$ & 0.774 & $\mathrm{~B} 1$ & B4 & B1 & 5.0 \\
\hline 5 & Pesquisa Agropecuária Brasileira & 0100-204X & 0.687 & B1 & B4 & B1 & 5.0 \\
\hline 6 & Neotropical Entomology & $1519-566 X$ & 0.646 & B1 & B4 & B1 & 5.0 \\
\hline 7 & Brazilian Journal of Microbiology & $1517-8382$ & 0.632 & $\mathrm{~B} 1$ & B4 & B1 & 5.0 \\
\hline 8 & Brazilian Journal of Biology & $1519-6984$ & 0.625 & B1 & B4 & B1 & 5.0 \\
\hline 9 & Ciência e Agrotecnologia & $1413-7054$ & 0.567 & B1 & B4 & B2 & 4.7 \\
\hline 10 & Natureza \& Conservação & $1679-0073$ & 0.565 & B1 & B4 & B2 & 4.7 \\
\hline 11 & Revista Brasileira de Ciência do Solo & $0100-0683$ & 0.532 & B1 & B4 & B2 & 4.7 \\
\hline 12 & Revista Brasileira de Entomologia & $0085-5626$ & 0.514 & B1 & B4 & B2 & 4.7 \\
\hline 13 & Crop Breeding and Applied Biotechnology & $1518-7853$ & 0.509 & B1 & B4 & B2 & 4.7 \\
\hline 14 & Tropical Plant Pathology & $1982-5676$ & 0.448 & B1 & B5 & B2 & 4.3 \\
\hline 15 & Revista Brasileira de Fruticultura & $0100-2945$ & 0.440 & B1 & B5 & B2 & 4.3 \\
\hline 16 & Acta Botanica Brasilica & $0102-3306$ & 0.368 & B1 & B5 & B2 & 4.3 \\
\hline 17 & Ciência Rural & $0103-8478$ & 0.343 & B1 & B5 & B2 & 4.3 \\
\hline 18 & Horticultura Brasileira & $0102-0536$ & 0.320 & B1 & B5 & B2 & 4.3 \\
\hline 19 & Revista Árvore & $0100-6762$ & 0.267 & B1 & B5 & B2 & 4.3 \\
\hline 20 & CERNE & $0104-7760$ & 0.238 & $\mathrm{~B} 1$ & B5 & B2 & 4.3 \\
\hline 21 & Bioscience Journal & $1516-3725$ & 0.203 & B1 & B5 & B2 & 4.3 \\
\hline 22 & Ciência Florestal & 0103-9954 & 0.191 & B1 & B5 & B2 & 4.3 \\
\hline 23 & Iheringia Série Botânica & $0073-4705$ & 0.156 & $\mathrm{~B} 1$ & B5 & B2 & 4.3 \\
\hline 24 & Acta Scientiarum. Technology & $1806-2563$ & 0.150 & B1 & B5 & B2 & 4.3 \\
\hline
\end{tabular}

$\mathrm{IF}=$ Impact Factor (JCR ISI).

AS = Agrarian Sciences I; BS = Biological Sciences I; BD = Biodiversity (Qualis CAPES). 
Eighty nine Brazilian scientific journals are indexed in ISI and also have a Qualis concept. Among then, 59 journals can publish papers with some information related to plants and then are able to receive manuscripts that can also be submitted to the journal Communications in Plant Sciences. However, only 24 journals have Impact Factor and are also presented in three areas of knowedge of the Qualis system (Agrarian Sciences I, Biological Sciences I and Biodiversity) (Table 1). Thus, these 24 journals publish the most potential papers that can be published by the journal Communications in Plant Sciences.

For comparison between the JCR and Qualis system for Brazilian journals, I opted to select the Qualis concept of the three areas of knowledge previously described. Following, I ranked the Qualis concept, so that $\mathrm{A} 1=8, \mathrm{~A} 2=7, \mathrm{~B} 1=6, \mathrm{~B} 2=5, \mathrm{~B} 3=4$, $\mathrm{B} 4=3, \mathrm{~B} 5=2$ and $\mathrm{C}=1$. After that, I calculated the average score of the three areas of knowledge of the Qualis system for comparison to the JCR system.

Brazilian journals were ranked by Impact Factor (Table 1). The most important Brazilian journal was the Anais da Academia Brasileira de Ciências, showing Impact Factor of 0.925 and the worst one was Acta Scientiarum. Technology, showing Impact Factor of 0.150 . However, comparing to the average Qualis score, four groups of journals were obtained with the same quality. Anais da Academia Brasileira de
Ciências, Scientia Agricola and Acta Scientiarum. Agronomy were the three main Brazilian journals, showing average Qualis score of 5.3 (Group 1). Journals ranked from 4 to 8 were the second most important journals, showing average Qualis score of 5.0 (Group 2). Other group of journals was ranked from 9 to 13 , showing average Qualis score of 4.7 (Group 3 ). And a group of journals ranked from 14 to 24 was the least important, showing average Qualis score of 4.3 (Group 4).

In the Group 1, Impact Factor varies from 0.805 to 0.925 (Table 1). In the Group 2, Impact Factor varies from 0.625 to 0.774 . In the Group 3, Impact Factor varies from 0.509 to 0.567 . In the Group 4, Impact Factor varies from 0.150 to 0.448 . These results showed that only in Group 4 can be observed high variance of the Impact Factor, so that, in theory, journals with very different qualities were classified in the same group. However, this problem was not verified in the Groups 1, 2 and 3.

I concluded that, in general, Qualis system can be very close to the JCR system, mainly for the "higher quality" journals, once a more elaborated analysis is performed using an average Qualis score.

Received on March 15, 2012.

Accepted on March 20, 2012.

Online published on March 23, 2012. 